\title{
EVALUATION OF BRAZILIAN CONTRIBUTION TO THE SUSTAINABLE DEVELOPMENT GOALS THROUGH GREEN CHEMISTRY: A SYSTEMIC REVIEW
}

Marcus Vinícius Amaral Leal Filho ${ }^{a}$, Maria das Graças Andrade Korn ${ }^{a, b}$, Lilian Lefol Nani Guarieiro ${ }^{a}$

a SENAI CIMATEC, Centro Integrado de Manufatura e Tecnologia, 41650-010, Salvador-BA, Brasil

b Instituto de Química, Universidade Federal da Bahia, 40170-115, Salvador, Bahia, Brasil

\begin{abstract}
The growing commitment of Chemistry to the Sustainable Development Goals (SDG) can be expressed through Green Chemistry. This work aims to evaluate the Brazilian contribution to sustainable development through Green Chemistry, in the area of Analytical Chemistry. It was possible to verify a greater number of publications related to the theme for institutions in 8 Brazilian states, with emphasis on São Paulo and Rio Grande do Sul. It was found that all articles evaluated contributed to SDG 12 by proposing analytical methods that reduce the amount of waste generated or propose replacement of toxic reagents / solvents with similar non-harmful ones. It can be concluded that the contribution of Brazilian researchers has been significant in different areas of analytical chemistry, including sample preparation, instrumentation and separation techniques.
\end{abstract}

Keywords: Sustainable Development Goals; Green Chemistry; Green Analytical Chemistry.

\section{AVALIAÇÃO DA CONTRIBUIÇÃO BRASILEIRA COM OS OBJETIVOS DE DESENVOLVIMENTO SUSTENTÁVEL ATRAVÉS DA QUÍMICA VERDE: UMA REVISÃO SISTÊMICA}

Resumo: O crescente compromisso da Química com os Objetivos de Desenvolvimento Sustentável (ODS) pode ser expresso através da Química Verde. O presente trabalho tem como objetivo avaliar a contribuição brasileira com 0 desenvolvimento sustentável através da Química Verde, na área de Química Analítica. Foi possível constatar um número maior de publicações relacionadas ao tema para instituições de 8 estados brasileiros, com destaque para São Paulo e Rio Grande do Sul. Verificou-se que todos os artigos avaliados contribuíram com o ODS 12 ao propor métodos analíticos que diminuem a quantidade de resíduos gerados ou propõem substituição de reagentes/solventes tóxicos por similares não nocivos. Pode-se concluir que a contribuição dos pesquisadores brasileiros tem sido significativa nas diferentes áreas da química analítica, entre elas preparo de amostras, instrumentação e técnicas de separação.

Palavras-chave: Objetivos de Desenvolvimento Sustentável; Química Verde; Química Analítica Verde. 


\section{INTRODUCTION}

The 2030 Agenda of the United Nations (UN) aims at Sustainable Development (SD) with a focus on the Planet and Humanity. To this end, 17 Sustainable Development Goals (SDGs) and 169 goals were proposed, which aim to promote SD through its three pillars: economic, social and environmental [1]. The growing commitment of Chemistry to the SDGs can be expressed through Green Chemistry (GC). This field aims to design processes and chemicals products to eliminate or reduce the use and formation of substances that are toxic to humans and to the environment. The term GC reflects the most sought objective, Sustainable Development, which can be defined as the current economic, industrial, and social progress without compromising the progress of future generations [2].

Chemistry, when analyzed as a final product (molecule), relates to the SDGs since it is present in health, means of production, well-being, food production, drinking water [3]. However, it is necessary to evaluate all the chemical procedures involved, from synthesis, separation, analysis processes, and to ensure that, throughout its development, good practices related to GC were used, such as: Management of reagents and laboratory waste, focusing identifying and reducing / replacing toxic reagents and recovering by-products; Atomic economy, optimizing reactions aiming at greater incorporation of atoms into the product; Preparation of samples for analysis using alternative methods; Use of continuous flow reactors. In this way, GC can be correlated with the SDGs: SDG 3 - Ensure healthy lives and promote wellbeing for all at all ages Goal; SDG 4 - Ensure inclusive and equitable quality education and promote lifelong learning opportunities for all; SDG 6 - Ensure availability and sustainable management of water and sanitation for all; and SDG 12 Ensure sustainable consumption and production patterns Goal. Analytical

Chemistry is the part of chemistry responsible for the determination and quantification of chemical elements in different types of samples. The effects of routine and polluting activities are harmful to the environment, regardless of whether they occur on an analytical scale or greater. Techniques such as High Performance Liquid Chromatography (HPLC) are responsible for generating 26 million to 52 million liters of chemical waste every year around the world [4]. Aiming at establishing environmentally friendly analytical procedure, the term Green Analytical Chemistry (GAC) has been used, which refers to analytical strategies related to GC that generate less waste, less toxic residues and presents better energy use [5]. Thus, the present work has the objective to carry out a systematic review on Green Chemistry together with Green Analytical Chemistry in Brazil and to evaluate the contribution of research in the area with the SDGs.

\section{METHODOLOGY}

The present study was defined in 5 stages for its realization. The first step consisted of searching for articles with the words "green chemistry" and "green analytical chemistry" in Portuguese and English. A research was carried out between $07 / 14 / 2020$ and $07 / 15 / 2020$ in the Scielo and Web of Science (WOS) indexes, articles published by Brazilian institutions between the years 2010 and 2020. The selected articles were those that demonstrated in the abstract the benefit (s) found with the study. After selection, the articles were evaluated to obtain data related to the SDGs that were achieved from the study. 


\section{RESULTS AND DISCUSSION}

The research made at Scielo with the words "Green Chemistry" and "Green Analytical Chemistry" for the years 2010 to 2020 presented 23 results, while the research realized at WOS for the word "Green Chemistry" and refined for "Chemistry Analytical", for the same period, it presented a result of 142 articles. Among the 165 studies found, those that presented in their abstract the benefits linked to GC found in the study in question and were available in full on the platforms were selected for later reading. Only 63 papers presented the advantages achieved in the abstract and were selected for reading to obtain data regarding the SDGs that were contemplated. Data were also collected on the institutions where the work was carried out.

After analysis of the articles, an increase in the number of published works can be seen, as shown in Figure 1, the 2020 year justified by the fact that the bibliographic review was carried out until the month of July of this year.

Figure 1. Number of articles evaluated about green chemistry per year (Period 2010-2020).

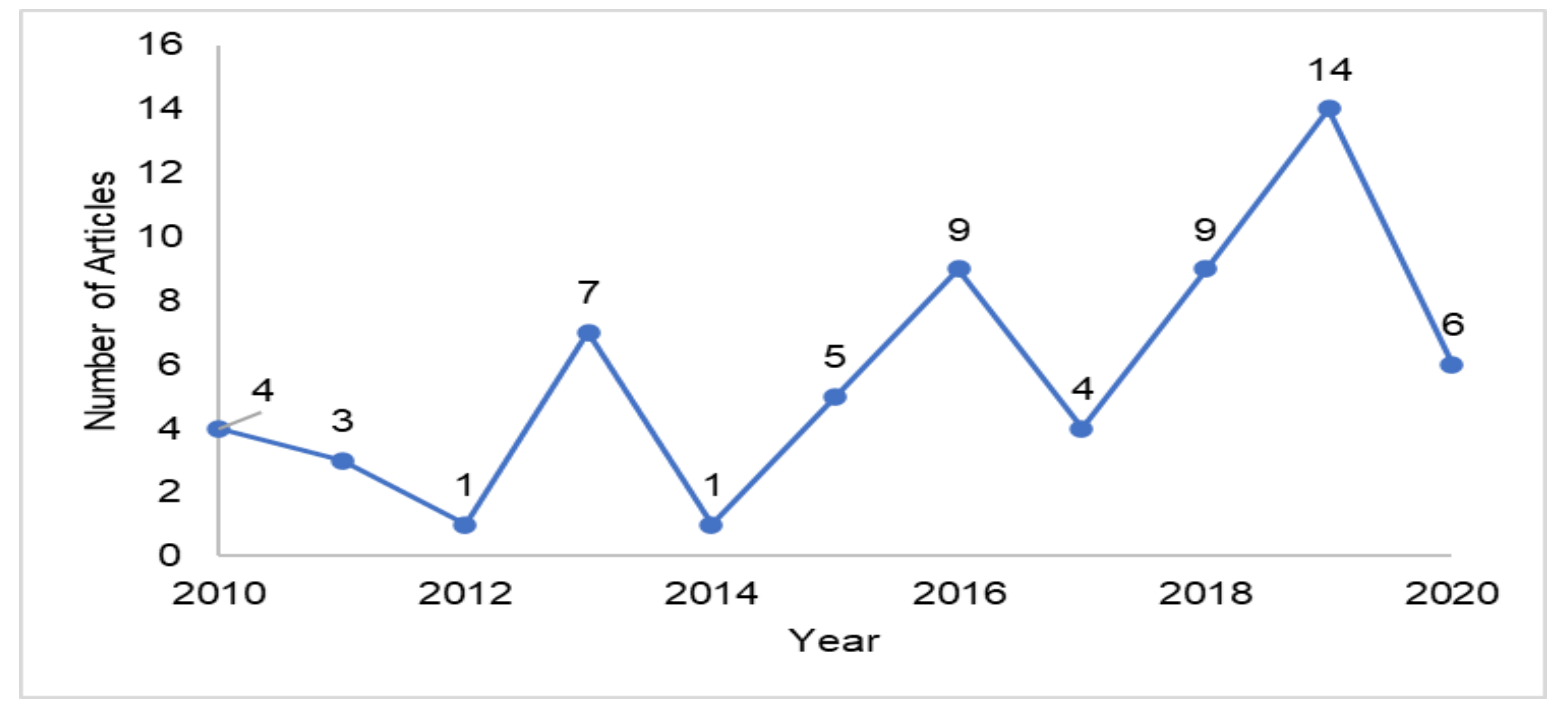

According to Figure 2, there is the participation of 9 Brazilian states, with outstanding performance from the states of São Paulo and Rio Grande do Sul, having together $65 \%$ of the total number of articles published with a focus on green chemistry.

Analysis of the number of publications by institutions was also made, with a significant contribution from the University of Sao Paulo (USP) with 14 publications, Federal University of Santa Maria (UFSM) with 12, followed by Paulista State University and Federal University of Paraíba with 8 and 7 articles respectively, as shown in Figure 3. Additionally, it is important to highlight the largest number of publications in some sub-areas, such as sample preparation and flow injection. New procedures have been proposed to reduce the number of steps as well as the amounts of sample and reagent, by downscaling and system miniaturization. 
Figure 2. Percentage of articles evaluated by state. Period: $2010-2020$

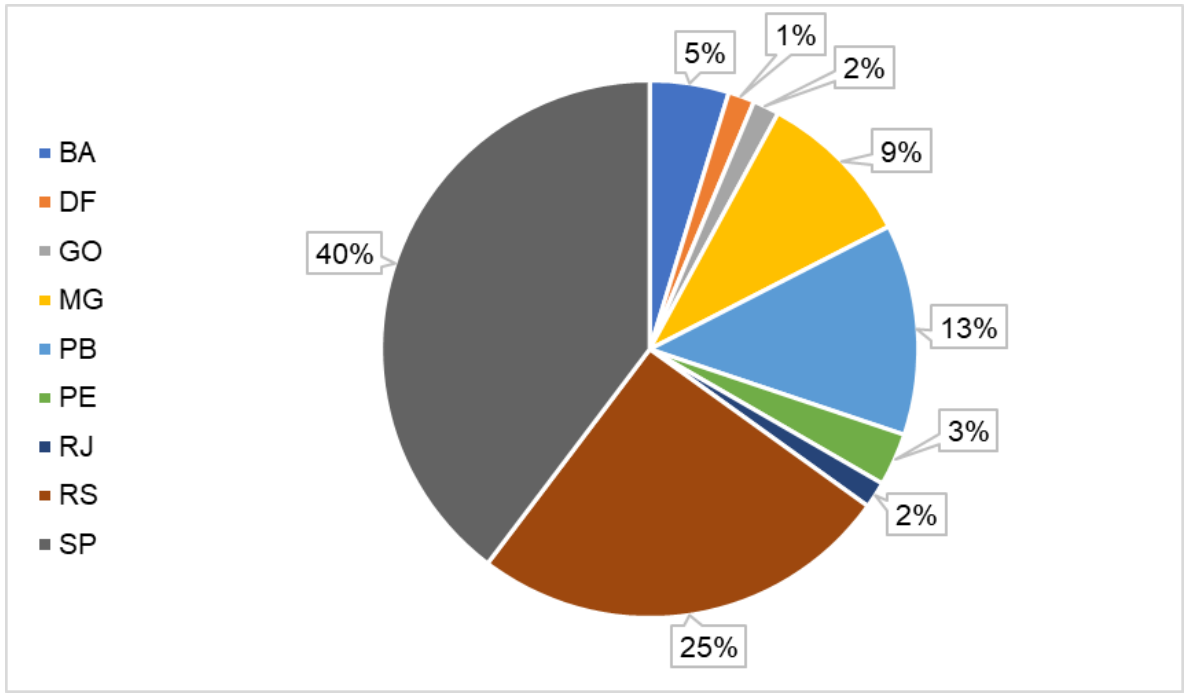

Figure 3. Number of publications by institutions. Period: 2010-2020

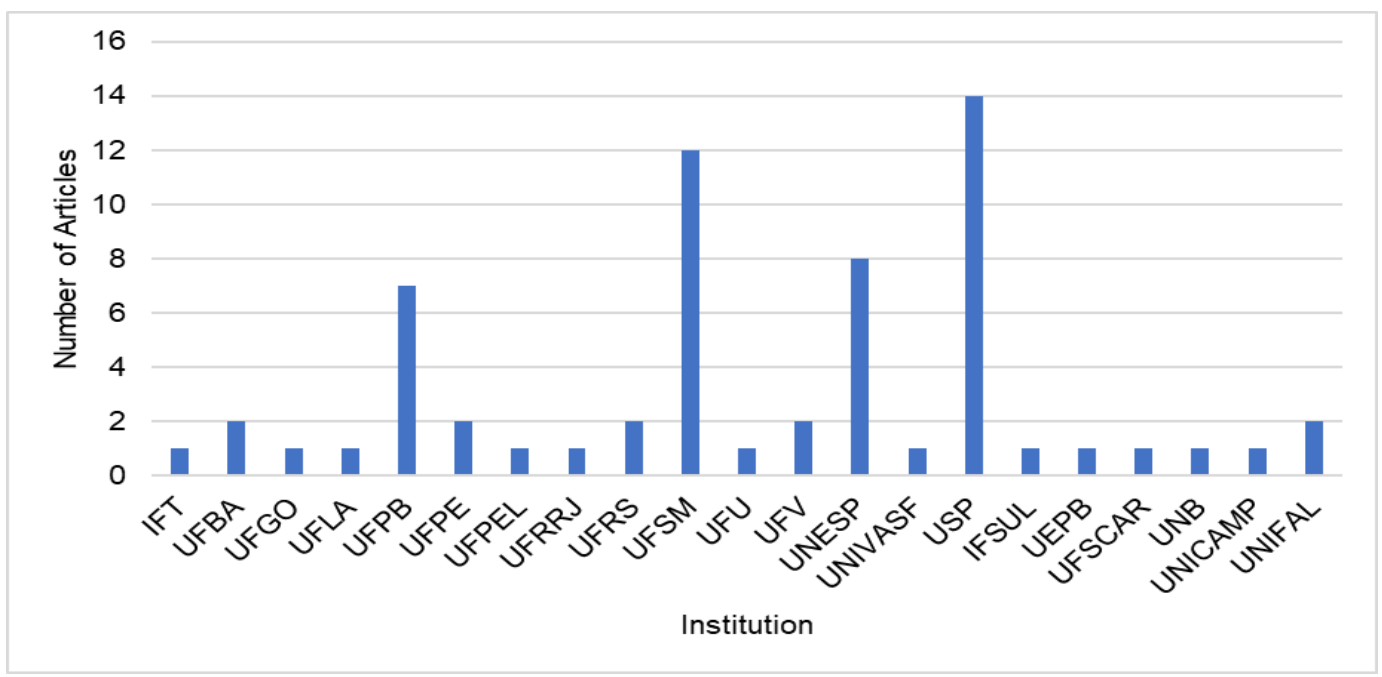

The evaluation of the contribution of the works developed in the selected articles with the SDGs is shown in Figure 4. It can be seen that the results described in the articles meet the recommendations of the following SDGs: SDG 3, SDG 4, SDG 6, SDG 11 and SDG 12.

All the articles studied showed concern with the waste generated and contributed to the SDG 12. Forty-eight evaluated articles proposed analytical methods that resulted in the reduction of waste generated [6 - 53] seven studies presented techniques that did not require chemical products [54 - 60] and nine studies suggested alteration of reagent / solvent for a similar less harmful to the environment and health [4,19,26,30,44,61-64].

In eighteen studies analyzed, it was found contributions to SDG 3. Lima et al, 2020 [25] proposed the determination of antimony, a bioaccumulative material that can cause diseases, in waters. Silva et al, 2019 [58] verified the presence of Benzo[a]pyrene, a carcinogen, in distillates. Nascimento et al, 2018 [23] determined 
the presence of pesticides, substances potentially harmful to health, in the atmospheric air, and Melchert and Rocha, 2010 [53] determined the presence of pesticides in water. Neri et al, 2019 [33] analyzed the presence of ions of copper in water, in excess copper can cause neurological, psychic diseases and even skin cancer. Lago et al, 2015 [36] made the determination of uranium in water. Muller et al, 2015 [37] verified the presence of toxic elements in medicinal plants. Batista and Rocha, 2013 [40] investigated the presence of bisphenol A, which can cause hormonal problems and proliferation of cancer cells, in water. Brondi et al, 2013 [43] determined sulfate in water. The other works $[4,19,26,44,51,61,62,64,65]$ reduce or replaced toxic reagents / solvents with other chemicals that perform the same function but are less harmful to the operator's health and the environment.

Figure 4. Evaluation of the contribution of the works developed in the selected articles with a focus on green chemistry with the SDGs. Period: 2010-2020

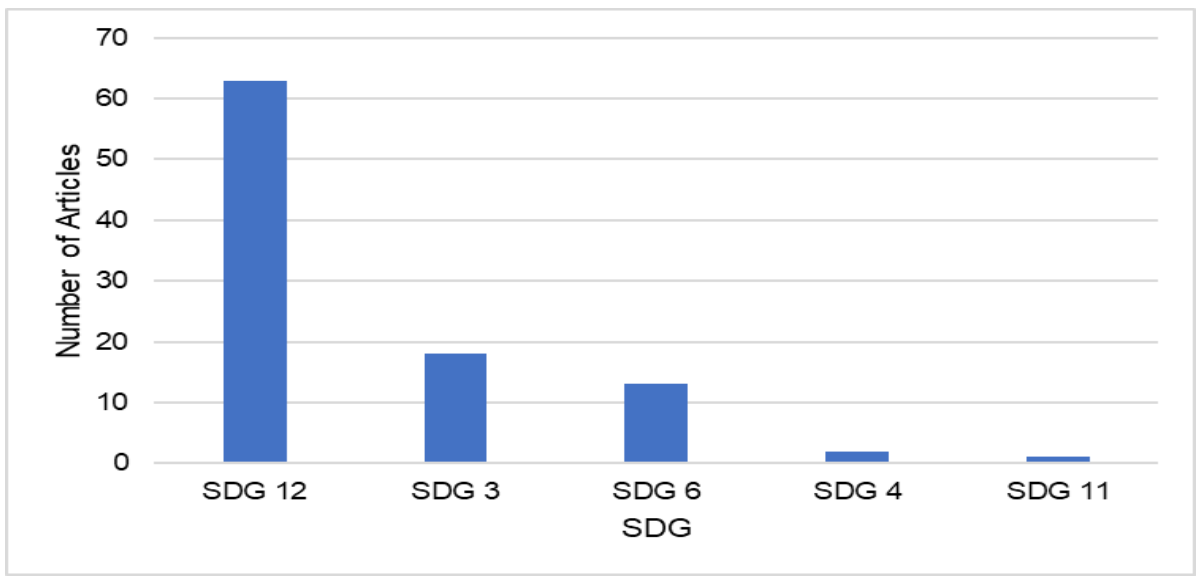

De Prá Urio and Masini, 2017 [15] evaluated in their work the presence of two herbicides, Simazine and Atrazine, in rivers. Damasceno et al, 2016 [21] proposed a new method for stipulating alkalinity and total hardness in drinking water, through digital images. Souza, Sasaki and Rocha, 2020 [24] made the determination of an emerging pollutant in water, salicylic acid. In addition to these three studies, eleven others $[25,33,36,39,40,42-45,51,53]$ also contributed to the SDG 6.

Two studies proposed analytical practices for graduation in accordance with the principles of GC $[65,66]$, meeting the recommendations of SDG 4. The use of the principles of GC in undergraduate courses at educational institutions should be encouraged, which should result in the training of professionals more aware of environmental problems and possible solutions.

Melchert and Rocha, 2010 [53] treated the waste generated in the experiment, and therefore contributed to SDG 11.Finally, according to Figure 5, the researchers who stood out as corresponding authors for the largest number of publications were: Fábio RP Rocha (USP), Juliano S. Barin (UFSM), Boaventura F. Reis, Erico MM Flores (UFSM) with 8, 6, 5 and 4 articles respectively 
Figure 5. Number of articles per corresponding author. Period: 2010-2020

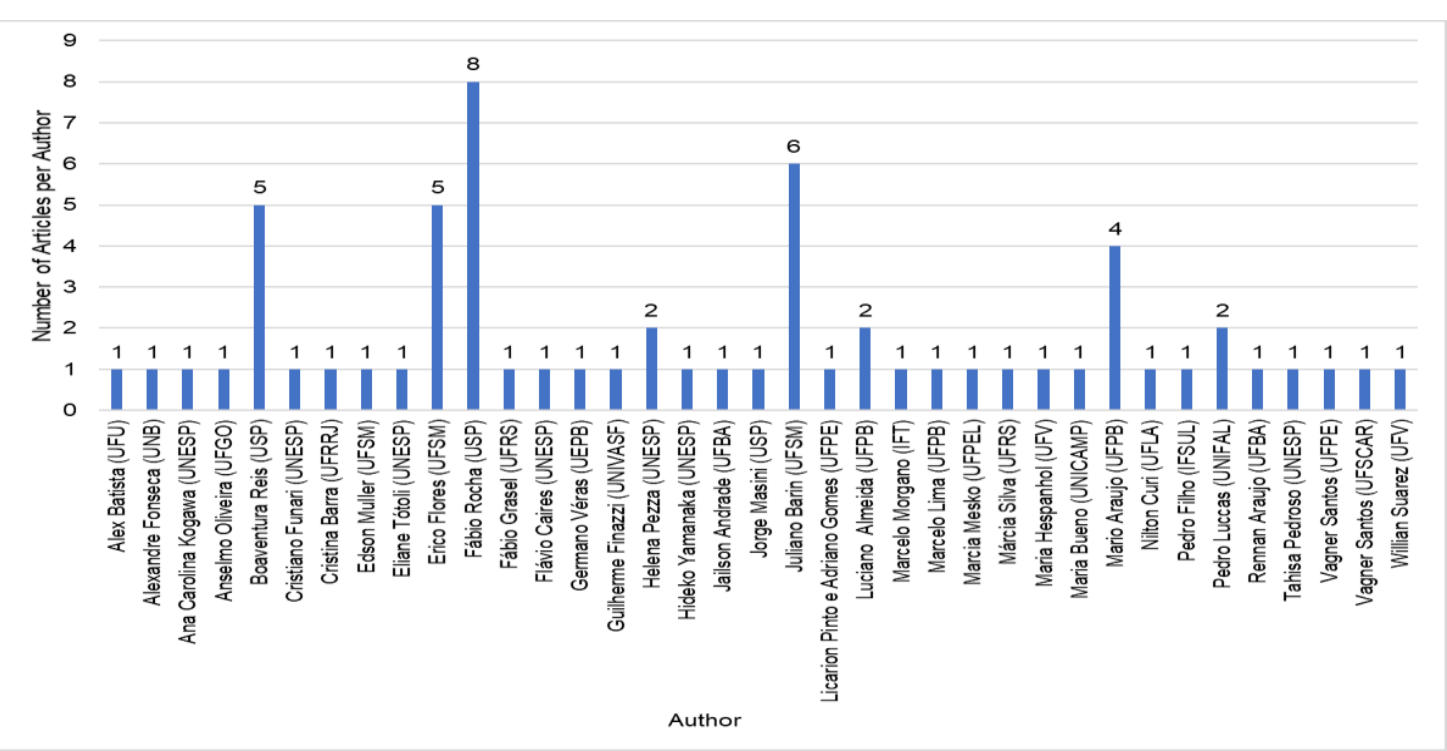

\section{CONCLUSION}

A significant number of analytical strategies have been proposed, showing that Brazilian researchers have developed new analytical methods to minimize waste generation without affecting species detection and the accuracy of analytical measures. The states that contributed most to the study were São Paulo, with 25 studies studied, followed by Rio Grande do Sul with 16. The institutions that most developed studies were the University of Sao Paulo (USP) with 14 publications, Federal University of Santa Maria (UFSM) with 12, followed by Paulista State University and Federal University of Paraíba with 8 and 7 articles respectively. It was possible to observe that all articles contributed to SDG 12, due to the implementation of cleaner analytical strategies proposed, with less waste generation. This can be demonstrated by an increase in the number of miniaturized methods and analysis using digital images, demonstrating the authors' effective concern with the generation of waste. In addition, a significant contribution to SDG was found, showing attention to chemicals that are toxic to health and the environment.

\section{REFERENCES}

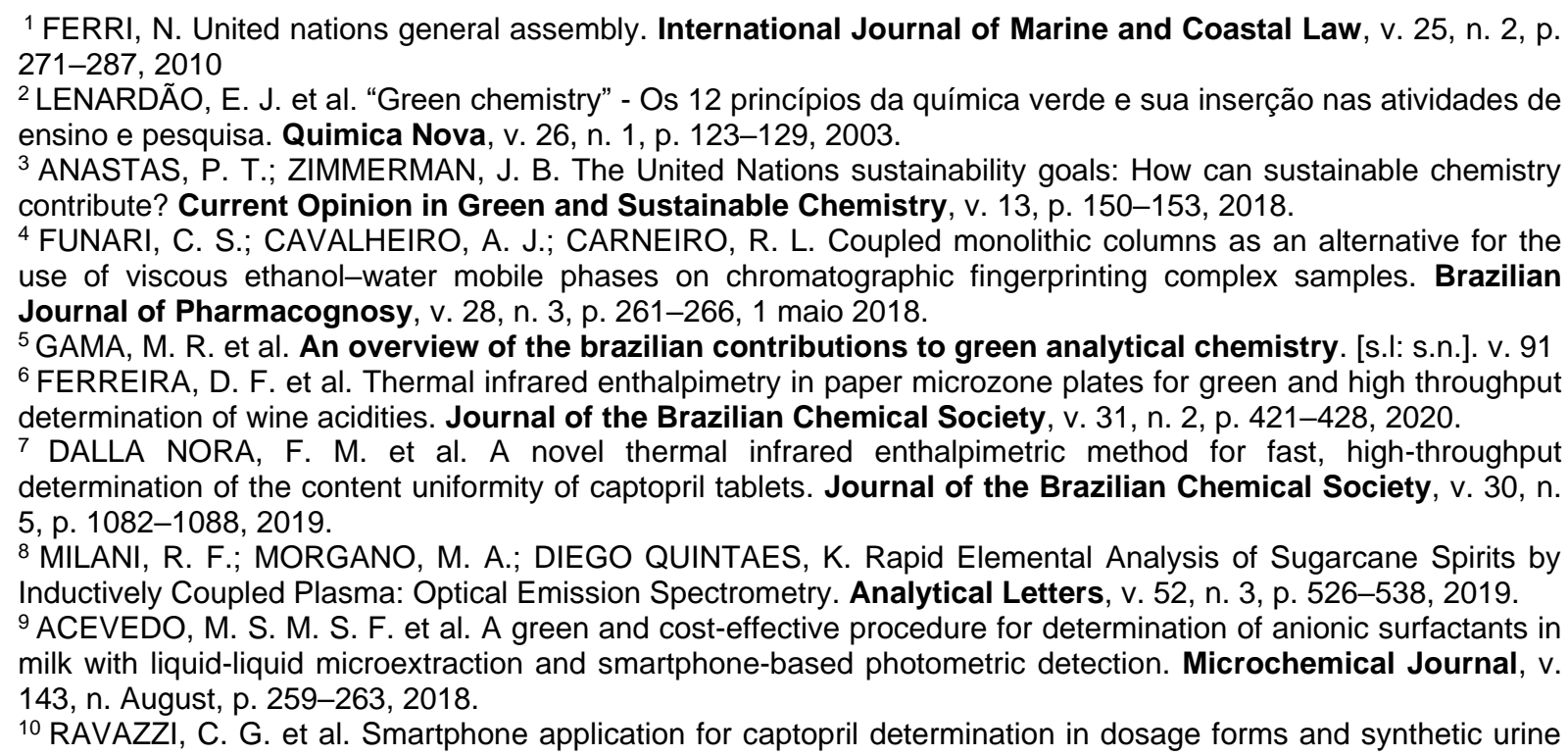


employing digital imaging. Talanta, v. 189, n. March, p. 339-344, 2018.

11 DALLA NORA, F. M. et al. Miniaturized, high-throughput and green determination of the saponification value of edible oils using thermal infrared enthalpimetry. Analytical Methods, v. 10, n. 30, p. 3770-3776, 2018.

$12 \mathrm{BIZZI}, \mathrm{C}$. A. et al. Maxwell-Wagner Effect Applied to Microwave-Induced Self-Ignition: A Novel Approach for Carbon-Based Materials. Analytical Chemistry, v. 90, n. 7, p. 4363-4369, 2018.

${ }^{13}$ ALMEIDA, P. L. et al. A rapid, sensitive and green analytical method for the determination of sulfite in vinegars using pararosaniline reaction with image detection. Analytical Methods, v. 10, n. 4, p. 448-458, 2018.

14 OLIVEIRA, A. S. et al. One-Shot, reagent-free determination of the alcoholic content of distilled beverages by thermal infrared enthalpimetry. Talanta, v. 171, n. May, p. 335-340, 2017.

15 DE PRÁ URIO, R.; MASINI, J. C. Determination of Simazine and Atrazine in River Water by Cloud-Point Extraction and High-Performance Liquid Chromatography. Analytical Letters, v. 50, n. 7, p. 1065-1074, 2017.

${ }_{16}$ MULLER, E. I. et al. Microwave-assisted wet digestion with $\mathrm{H} 2 \mathrm{O} 2$ at high temperature and pressure using single reaction chamber for elemental determination in milk powder by ICP-OES and ICP-MS. Talanta, v. 156157, p. 232-238, 2016.

17 PEREIRA, L. S. F. et al. Determination of elemental impurities in poly(vinyl chloride) by inductively coupled plasma optical emission spectrometry. Talanta, v. 152, p. 371-377, 2016.

18 SOARES, S.; ROCHA, F. R. P. Fast spectrophotometric determination of iodine value in biodiesel and vegetable oils. Journal of the Brazilian Chemical Society, v. 29, n. 8, p. 1701-1706, 1 ago. 2018.

${ }^{19}$ CASTOLDI, K. et al. Flow injection analysis of 5-(hydroxymethyl)-2-furaldehyde in honey by a modified winkler method. Analytical Sciences, v. 32, n. 4, p. 413-417, 2016.

20 LIMA, M. J. A. et al. Development of a new procedure for the determination of captopril in pharmaceutical formulations employing chemiluminescence and a multicommuted flow analysis approach. Luminescence, v. 31, n. 1, p. 288-294, 2016.

21 DAMASCENO, D. et al. CompVis: A novel method for drinking water alkalinity and total hardness analyses. Analytical Methods, v. 8, n. 43, p. 7832-7836, 2016.

22 PINTO, L. et al. Handling time misalignment and rank deficiency in liquid chromatography by multivariate curve resolution: Quantitation of five biogenic amines in fish. Analytica Chimica Acta, v. 902, p. 59-69, 2016.

23 NASCIMENTO, M. M.; DA ROCHA, G. O.; DE ANDRADE, J. B. A rapid low-consuming solvent extraction procedure for simultaneous determination of 34 multiclass pesticides associated to respirable atmospheric particulate matter (PM2.5) by GC-MS. Microchemical Journal, v. 139, p. 424-436, 2018.

${ }^{24}$ SOUZA, P. A. F.; SASAKI, M. K.; ROCHA, F. R. P. Exploitation of a short monolithic column for in-line separation and preconcentration: Environmental friendly determination of the emerging pollutant salicylic acid in natural waters. Journal of Separation Science, v. 43, n. 7, p. 1232-1239, 2020.

${ }_{25}$ LIMA, E. A. et al. A fast and sensitive flow-batch method with hydride generating and atomic fluorescence spectrometric detection for automated inorganic antimony speciation in waters. Talanta, v. 207, n. February 2019 , p. 119834, 2020.

26 TÓTOLI, E. G.; SALGADO, H. R. N. Miniaturized turbidimetric assay: A green option for the analysis of besifloxacin in ophthalmic suspension. Talanta, v. 209, n. October 2019, p. 120532, 2020.

27 DE OLIVEIRA, L. M. A. et al. An environment-friendly spot test method with digital imaging for the microtitration of citric fruits. Talanta, v. 206, n. July 2019, p. 120219, 2020.

${ }^{28}$ FERREIRA, H. S. et al. Characterisation of the mineral composition of tobacco products (cigar, shredded and rope). Microchemical Journal, v. 151, n. June, p. 104196, 2019.

29 BRASIL, M. A. S.; REIS, B. F. An automated multicommuted flow analysis procedure for photometric determination of reducing sugars in wine employing a directly heated flow-batch device. Journal of the Brazilian Chemical Society, v. 28, n. 10, p. 2013-2020, 2017.

30 ALESSIO, K. O. et al. Infrared thermal imaging combined with paper microzone plates and natural reagent extracts for simple, fast, and green enthalpimetric analysis. Talanta, v. 204, n. January, p. 266-271, 2019.

31 VOSS, M. et al. Feasibility of paper microzone plates for greener determination of the alcoholic content of beverages by thermal infrared enthalpimetry. Analytical Methods, v. 11, n. 39, p. 4983-4990, 2019.

32 LIMA, M. J. A.; REIS, B. F. Photogeneration of silver nanoparticles induced by UV radiation and their use as a sensor for the determination of chloride in fuel ethanol using a flow-batch system. Talanta, v. 201, n. January, p. 373-378, 2019.

33 NERI, T. S. et al. Highly sensitive procedure for determination of $\mathrm{Cu}(\mathrm{II})$ by GF AAS using single-drop microextraction. Microchemical Journal, v. 147, n. October 2018, p. 894-898, 2019.

34 PEREIRA, R. M. et al. Multitechnique determination of metals and non-metals in sports supplements after microwave-assisted digestion using diluted acid. Microchemical Journal, v. 145, n. October 2018, p. 235-241, 2019.

${ }^{35}$ LIMA, M. J. A.; KAMOGAWA, M. Y.; REIS, B. F. A new sensitive photometric procedure for the determination of sulfate in fuel ethanol without sample preparation exploiting a flow-batch strategy. Microchemical Journal, v. 145, n. November 2018, p. 921-926, 2019.

${ }^{36}$ LAGO, A. C. DO et al. Determination of Uranium in Environmental Water by Flow Injection Analysis using a Hybrid-Imprinted Polymer. Analytical Letters, v. 48, n. 17, p. 2739-2753, 2015.

37 MULLER, A. L. H. et al. Microwave-assisted digestion using diluted acids for toxic element determination in medicinal plants by ICP-MS in compliance with United States pharmacopeia requirements. Analytical Methods, v. 7, n. 12, p. 5218-5225, 2015.

${ }^{38}$ LIMA, M. B. et al. In-line single-phase extraction for direct determination of total iron in oils using CdTe quantum dots and a flow-batch system. Analytical Methods, v. 7, n. 18, p. 7707-7714, 2015. 
39 BEZERRA DOS SANTOS, V. et al. A versatile and robust electrochemical flow cell with a boron-doped diamond electrode for simultaneous determination of $\mathrm{Zn} 2+$ and $\mathrm{Pb} 2+$ ions in water samples. Analytical Methods, v. 6, n. 21, p. 8526-8534, 2014.

40 BATISTA, A. D.; ROCHA, F. R. P. A green flow-injection procedure for fluorimetric determination of bisphenol A in tap waters based on the inclusion complex with $\beta$-cyclodextrin. International Journal of Environmental Analytical Chemistry, v. 93, n. 13, p. 1402-1412, 2013.

41 DE JESUS, A. et al. Determination of mercury in naphtha and petroleum condensate by photochemical vapor generation atomic absorption spectrometry. Microchemical Journal, v. 110, p. 227-232, 2013.

42 NÓBREGA, L. N. N.; MAGALHÃES, L. DE O.; FONSECA, A. A urethane-acrylate microflow-analyzer with an integrated cadmium column. Microchemical Journal, v. 110, p. 553-557, 2013.

43 BRONDI, A. M. et al. A Single FIA system coupled with reduction and distillation processes for the determination of sulfate ion by spectrophotometry. Analytical Sciences, v. 29, n. 5, p. 559-562, 2013.

44 ROCHA, D. L.; ROCHA, F. R. P. An environmentally friendly flow-based procedure with photo-induced oxidation for the spectrophotometric determination of chloride in urine and waters. Microchemical Journal, v. 108, p. 193-197, 2013.

45 PEREIRA, A. C.; ROCHA, F. R. P. A multicommuted flow system with liquid-liquid microextraction for determination of anionic surfactants in freshwaters. Analytical Methods, v. 5, n. 8, p. 2104-2109, 2013.

46 LIMA, M. B. et al. A digital image-based micro-flow-batch analyzer. Microchemical Journal, v. 106, p. 238243, 2013.

47 PICOLOTO, R. S. et al. Mercury determination in soil by CVG-ICP-MS after volatilization using microwaveinduced combustion. Analytical Methods, v. 4, n. 3, p. 630-636, 2012.

48 ULIANA, C. V.; TOGNOLLI, J. O.; YAMANAKA, H. Application of factorial design experiments to the development of a disposable amperometric DNA biosensor. Electroanalysis, v. 23, n. 11, p. 2607-2615, 2011.

${ }^{49}$ MONTE-FILHO, S. S. et al. Flow-batch miniaturization. Talanta, v. 86, n. 1, p. 208-213, 2011.

$50 \mathrm{BIZZI}, \mathrm{C}$. A. et al. Evaluation of oxygen pressurized microwave-assisted digestion of botanical materials using diluted nitric acid. Talanta, v. 83, n. 5, p. 1324-1328, 2011.

${ }^{51}$ MELCHERT, W. R.; OLIVEIRA, D. R.; ROCHA, F. R. P. An environmentally friendly flow system for highsensitivity spectrophotometric determination of free chlorine in natural waters. Microchemical Journal, v. 96, $n$. 1, p. 77-81, 2010.

52 BORGES, S. S. et al. Downscaling a multicommuted flow injection analysis system for the photometric determination of iodate in table salt. Analytica Chimica Acta, v. 668, n. 1, p. 3-7, 2010.

53 MELCHERT, W. R.; ROCHA, F. R. P. A greener and highly sensitive flow-based procedure for carbaryl determination exploiting long pathlength spectrophotometry and photochemical waste degradation. Talanta, $\mathrm{v}$. 81 , n. 1-2, p. 327-333, 2010.

${ }^{54}$ SILVA, S. H. G. et al. Modeling and prediction of sulfuric acid digestion analyses data from pxrf spectrometry. Scientia Agricola, v. 77, n. 4, 2020.

${ }_{55}$ GRASEL, F. S. et al. Principal component analysis of commercial tannin extracts using digital images on mobile devices. Journal of the Brazilian Chemical Society, v. 27, n. 12, p. 2372-2377, 12 jan. 2016.

56 RIBEIRO, F. C. P. et al. Detection oxidative degradation in lubricating oil under storage conditions using digital images and chemometrics. Microchemical Journal, v. 147, n. October 2018, p. 622-627, 2019.

57 GAGLIERI, C. et al. Is Thermogravimetry an efficient alternative to gas chromatography in degree of biodiesel conversion? Journal of Thermal Analysis and Calorimetry, v. 135, n. 4, p. 2591-2597, 2019.

58 SILVA, A. C. et al. Green chemistry method based on PARAFAC EEM data modeling for Benzo[a]pyrene quantitation in distilled spirit. Journal of the Brazilian Chemical Society, v. 30, n. 2, p. 398-405, 2019.

${ }^{59}$ COSTA, G. B. et al. Digital image-based classification of biodiesel. Talanta, v. 139, p. 50-55, 2015.

60 TERRA, J. et al. Um método verde, rápido e simples para determinar o valor energético de farinhas e cereais matinais. Química Nova, v. 33, n. 5, p. 1098-1103, 2010.

61 CAMPOS, R. A. et al. Green speciation of iron using aqueous two-phase system. Anais da Academia Brasileira de Ciencias, v. 90, n. 2, p. 1929-1944, 2018.

62 KOGAWA, A. C.; VAN SCHEPDAEL, A.; SALGADO, H. R. N. Eco-friendly evaluation of rifaximin in tablets by capillary electrophoresis. Journal of Chromatographic Science, v. 57, n. 5, p. 476-483, 2019.

${ }^{63}$ PEDROSO, T. M.; MEDEIROS, A. C. D.; SALGADO, H. R. N. RP-HPLC $\times$ HILIC chromatography for quantifying ertapenem sodium with a look at green chemistry. Talanta, v. 160, p. 745-753, 2016.

64 MILANI, M. I. et al. Development of a new clean methodology with ultrasound-assisted extraction for analysis of sodium in pet foods. Analytical Methods, v. 7, n. 6, p. 2433-2436, 2015.

65 VIEIRA, B. H. S. et al. Substituição do nitrobenzeno pelo óleo de soja como uma proposta para o ensino do método de Volhard em análise quantitativa. Quimica Nova, v. 40, n. 9, p. 1130-1135, 1 set. 2017.

66 FINAZZI, G. A. et al. Desenvolvimento de experimento didático de eletrogravimetria de baixo custo utilizando princípios da química verde. Quimica Nova, v. 39, n. 1, p. 112-117, 1 jan. 2016. 